\title{
Perceived Stress, Burnout Levels and Healthy Behaviors of Family Medicine Residents: The Impact of a Psychoeducational Program
}

\author{
Aile Hekimliği Asistanlarının Stres Algıları, Tükenmişlik Düzeyleri ve \\ Sağlık Davranışları: Bir Psikoeğitim Programının Etkisi
}

\author{
Havva Bölükbaşı ${ }^{1}$, Sevgi Özcan ${ }^{2}$
}

\begin{abstract}
Aim: The aim of this study is to implement a structured stress management program to the family medicine residents and to evaluate the impact of this upon the residents' perceived stress, level of burnout, health behaviors and problem solving skills. Methods: The sample of the study which was planned as selfcontrolled experimental design constituted the family medicine residents majoring in family medicine $(n=26)$ at our faculty, at the time when the study was conducted. Residents were given psycho education, related to stress management and social problem solving, one hour per week for eight weeks. They completed the following scales at the beginning, at the end of the educational program (month two) and the follow-up period (month 6): Perceived Stress Scale, Maslach Burnout Inventory (emotional exhaustion, depersonalization and personal accomplishment), Healthy Lifestyle Behaviors Scale-II (nutrition, physical activity, stress management, interpersonal relationships, spirituality, healthy responsibility) and Social Problem Solving Inventory (orientation, resolution, total). Besides, a questionnaire which was developed by us and which evaluated the training was performed when the training ended. Results: Of the participants $65.4 \%$ were female. The mean age was $29.8 \pm 3.0$ years. There were significant changes in all mean scores $(\mathrm{p}<0.05)$ after educational program, except for the perceived stress, emotional exhaustion and depersonalization score. At month six, it was observed that the significant differences of changes were continued for nutrition, stress management, interpersonal relationships, spirituality, orientation, healthy lifestyle behaviors total and social problem

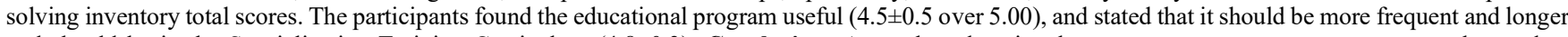
and should be in the Specialization Training Curriculum (4.8 \pm 0.3 ). Conclusion: A psycho educational program on stress management was observed to influence the burnout levels, health behaviors and social problem solving skills of the family medicine residents positively and this effect continued in sixth month.
\end{abstract}

Key words: Family medicine, stress, burnout, residency, education

\section{ÖZET}

Amaç: Bu çalışmanın amacı, aile hekimi asistanlarına yapılandırılmış bir stres yönetimi programı uygulanması ve bunun asistanların algılanan stres, tükenmişlik düzeyleri, sağlık davranışları ve sorun çözme becerilerine etkisinin değerlendirilmesidir. Yöntem: Kendi kendine kontrollü deneysel tipte planlanan çalışmanın örneklemini, araştırmanın yapıldığı tarihte fakültemizde uzmanlık eğitimi alan aile hekimliği asistanları oluşturmuş̧ur (n=26). Asistanlara sekiz hafta boyunca, haftada bir saat stres yönetimi ve sosyal sorun çözmeyle ilgili psikoeğitim verilmiştir. Başlangıçta, eğitimin bitiminde (ikinci ay) ve izlem döneminde (altıncı ay) olmak üzere toplam üç kez 1) Algılanan Stres Ölçeği, 2) Maslach Tükenmişlik Envanteri (duygusal tükenme, duyarsızlaşma ve kişisel başarı), 3) Sağlıklı Yaşam Biçimi Davranışları Ölçeği- II (beslenme, fiziksel aktivite, stres yönetimi, kişilerarası ilişkiler, tinsellik, sağlık sorumluluğu) ve 4) Sosyal Sorun Çözme Envanteri (yönelim, çözüm, toplam) uygulanmıştır. Ayrıca eğitim bitiminde, tarafımızca oluşturulan ve

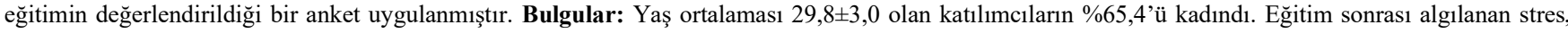
duygusal tükenme ve duyarsızlaşma ölçek puanları dışındaki tüm ölçek puan ortalamalarının anlamlı değişim gösterdiği bulunmuştur ( $p<0,05$ ). Altıncı ayda, beslenme, stres yönetimi, kişilerarası ilişkiler, tinsellik, yönelim, sağlıklı yaşam davranışları toplam ve sorun çözme toplam puanlarındaki değişimin anlamlı farklılığının devam ettiği saptanmışır. Katılımcılar, eğitim programının genel olarak yararlı olduğunu $(4,5 \pm 0,5)$, bu eğitimin asistan eğitim programında yer alması gerektiğini $(4,8 \pm 0,3)$ bildirmişler ve eğitimin daha sık, daha uzun süreli, öğle arası yerine daha geniş zaman dilimlerinde yapılmasını önermişlerdir. Sonuç: Stres yönetimiyle ilgili bir psikoeğitim programının, aile hekimliği asistanlarının tükenmişlik düzeylerini, sağlık davranışlarını ve sosyal sorun çözme becerilerini olumlu etkilediği ve bu etkinin altı ay sonrasında da devam ettiği gözlemlenmiştir.

Anahtar kelimeler: Aile hekimliği, stres, tükenmişlik, asistanlık, eğitim

Received / Geliș tarihi: 15.05.2019, Accepted / Kabul tarihi: 26.06.2019

${ }^{1}$ İskenderun 6 Nolu Hacı Şerif Tosyalı ASM, Hatay

${ }^{2}$ Cukurova Üniversitesi Tıp Fakültesi Aile Hekimliği Anabilim Dalı, Adana

*Address for Correspondence / Yazışma Adresi: Sevgi Özcan Çukurova Üniversitesi Tıp Fakültesi Aile Hekimliği Anabilim Dalı, Adana

E-mail: spayciozcan@gmail.com

Bölükbaşı H, Özcan S. Aile Hekimliği Asistanlarının Stres Algıları, Tükenmişlik Düzeyleri ve Sağlık Davranışları: Bir Psikoeğitim Programının Etkisi TJFMPC, 2019;13 (4): 437-447.

DOI: $10.21763 / \mathrm{tjfmpc.648991}$ 


\section{GíRiș}

Hekimlerin, işte yüksek düzeyde strese maruz kaldıkları bilinmektedir. Eğer stresle başa çıkılamaz ve uyum sağlanamaz ise tükenme aşamasına geçilmektedir. ${ }^{1-5}$ Tükenmişlik, duygusal tükenme, duyarsızlaşma ve kişisel başarıda azalma boyutları ile değerlendirilmektedir. Duygusal tükenme, iş hayatında aşırı derecede psikolojik ve duygusal taleplere maruz kalmaktan dolayı, enerjinin bitmesi durumunu ifade etmektedir. Duyarsızlaşma, bireyin hizmet verdiklerine karşı bu kişilerin bir birey olduklarını dikkate almaksızın duygudan yoksun tutum ve davranışlar sergilemesidir. Kişisel başarıda azalma ise, kişinin kendisini işinde yeterli ve başarılı hissetmemesi durumunu tanımlamaktadır. ${ }^{5}$ On iki Avrupa ülkesini kapsayan çalışmaya göre, genel olarak tükenmişlik aile hekimlerinin üçte ikisini etkileyen ortak bir sorundur, ancak ülkelere göre prevalansı çok geniş bir aralığa sahiptir (duygusal tükenme \%15-68, duyarsızlaşma \%12-73, kişisel başarıda azalma \%12-93). Ülkemiz için bu oranlar sırasıyla $\% 15,2, \% 15,2$ ve $\% 69,4$ şeklindedir. ${ }^{1}$

Aslında tükenmişliğin tıp eğitimi yıllarında başladığ ve çalışma yaşamında olgunlaştığ düşünülmektedir. ${ }^{6-9} \quad$ Asistanların tükenmişlik yaşamalarında; iş stresinin, eğitimlerindeki kültürel dinamiklerin, hasta taleplerinin, klinik olarak üsttekilerin davranışlarının, kişisel özelliklerinin, yaşadığı olumsuzlukların, düzensiz ve yetersiz uyku gibi faktörlerin rol oynadığı gösterilmiştir. ${ }^{9}$ Bununla birlikte, iş-aile çatışmasının en yoğun yaşandı̆̆ 1 dönemlerden birinin asistanlık dönemi olduğu saptanmış, hekimliğin bu sürecinde asistanların yoğun iş yaşamlarının yanı sıra evlilik, çocuk sahibi olma gibi birçok özel yaşam olayını yönetmek ve bunlardan kaynaklanan sorunlarla da baş etmek durumunda kaldıkları vurgulanmıştır. ${ }^{10}$

Asistanlardaki stres ve tükenmişlik, sadece kendilerinin yaşam kalitelerini değil diğer insanlarla ilişskilerini ve verdikleri sağlık hizmetini de etkilemektedir. ${ }^{9}$ Asistanların çoğunun tükenmişliğin farkında olmadıkları, stres yönetimi eğitimi almadıkları ve asistanlık döneminde stres yönetim programına ihtiyaçları olduğu ortaya konmuştur. ${ }^{11}$ Tükenmişlikle mücadele için standardize yöntemler, onaylanmış ölçümler kullanılarak başarılı stratejiler belirlemek, böylece asistan hekimlerin ve hastaların iyilik halini arttırmak gerektiği bildirilmiştir ${ }^{8}$. Ancak yaygın olmasına ve ciddi sonuçlarına rağmen, stresle ve tükenmişlikle mücadeleye yönelik çok az sayıda girişime rastlanmıştır. ${ }^{8}$ Mc Gray ve arkadaşları 1966-2007 yılları arasındaki literatürü gözden geçirerek yayınladıkları derlemede dahil etme kriterlerini karşılayan (asistan hekim, tıp öğrencisi, randomize kontrollü çalışmalar, randomize olmayan kontrollü çalışmalar, pre-post modeli, müdahaleli longitidunal kohort çalışmalar) altısı asistanlara yönelik toplam dokuz çalışma bulmuşlardır ve bunların sadece ikisi randomize kontrollü çalışmadır. Çalışmalarda bahsedilen girişimler, çalıştay, asistan destek programı, kendi kendine müdahale, destek grupları, didaktik oturumlar ve stres yönetimi/baş etme eğitimleri şeklinde yapılmıştır. $^{8} \mathrm{Bu}$ konuda başarılı stratejiler belirleyebilmek için standardize yöntemlerin, daha büyük örneklerin, geçerli-güvenilir ve kabul edilmiş ölçeklerin kullanıldığı daha fazla girişimsel çalışmaya gereksinim olduğu bildirilmiştir. ${ }^{2,8}$

Stres yönetimi programları, gevşeme egzersizlerinden bilişsel davranışçı ve hasta odaklı terapiye kadar değişebilmektedir. ${ }^{12}$ Sosyal sorun çözme terapisi, bilişsel davranışçı yöntemlerden biridir ve aynı zamanda aile hekimlerinin birçok psikososyal sorunun yönetiminde kullanabilecekleri etkili bir yöntem olarak önerilmektedir ${ }^{13-16}$. Sağlıklı yaşam davranışlarının uygulanması stres yönetiminde önerilen bir diğer yöntemdir ve aile hekimlerinin kendilerinin sağlıklı davranışları uygulamaları durumunda, bu konuda hastalarına etkin danışmanlık vermelerinin daha olası olduğu bildirilmiştir. ${ }^{17}$

Ülkemizde, asistanlık dönemindeki sorunlarla ilgili durum tespitine yönelik birçok çalışma olmasına karşın stres veya tükenmişlikle ilgili girişimsel bir çalışmaya rastlanmamıştır. ${ }^{18-29}$ $\mathrm{Bu}$ çalışmada, sorun çözme terapisini içeren yapılandırılmış bir stres yönetimi programı uygulanması ve bunun asistan hekimlerin algilanan stres, tükenmişlik düzeyleri, sağlık davranışları ve sorun çözme becerilerine etkisinin değerlendirilmesi amaçlanmıştır.

\section{YÖNTEM}

\section{Çalışmanın Tasarımı}

Tanımlayıcı ve kendi kendine kontrollü deneysel tipte planlanan çalışmanın örneklemini, araştırmanın yapıldığg1 tarihlerde (Ekim 2014-Mayıs 2015) Çukurova Üniversitesi Tıp Fakültesi'nde uzmanlık eğitimi almakta olan aile hekimliği asistanları $(n=26)$ oluşturmuştur. Araştırma başladıktan sonra uzmanlık eğitimine başlayan asistanlar çalışmaya dâhil edilmemiştir. $\mathrm{Bu}$ çalışma ... Üniversitesi Bilimsel Araştırma Projeleri tarafından TTU-20143109 numarası ile desteklenmiştir. Çukurova Üniversitesi Tıp Fakültesi Etik Kurulu (16 Haziran 2014, Karar no: 10) tarafından onaylanmıştır.

Çalışmaya katılmayı kabul eden asistanlara (tamamı), stres yönetimi, sosyal sorun çözme ve bilişsel davranışçı terapi ile ilgili eğitim almış aile hekimliği akademisyeni tarafından yapılandırılmış bir eğitim modeli (psikoeğitim) uygulanmıştır. 
Psikoeğitim, bireylerin stres yönetimi ve ruh sağlıklarını korumaları, bununla ilgili yeterlilik kazanmalarına yardımcı olacak bir müdahaledir. Bireylere bilgi ve beceri aktarılması, grup oturumları ve ev ödevleri sayesinde sağlanmıştır. Bu eğitim sırasında katılımcılara genel bilgiler, temel ipuçları ve teknikler sunulmaktadır. İkinci fazda bu bilgileri bağımsız olarak işlemek ve uygulamak gelmektedir. Ev ödevleri sayesinde katılımcılar, genel bilgiyi kendi durumları için kişiselleştirme firsatı bulmaktadır. Psikoeğitim bilgi ve beceri kazanma konusunda katılımcıları güçlendirilmesine rağmen bireylerin öğrendiklerini uygulaması kendi sorumluluklarındadır. ${ }^{30}$

Eğitim, sekiz ardışık hafta, haftada bir 60 dakikalık oturumlar şeklinde planlanmıştır. Eğitim programı ve içeriği Tablo 1 ve 2 de görüldüğü gibi yapılandırılmıştır.

\section{Tablo 1. Bir oturumun yapılandırılması}

\begin{tabular}{|l|l|}
\hline Süre & İçerik \\
\hline $\mathbf{1 0}$ & $\begin{array}{l}\text { Giriş } \\
\text { Bir önceki oturumun özetlenmesi } \\
\\
\text { Ev ödevlerinin değerlendirilmesi }\end{array}$ \\
\hline $\mathbf{4 5}$ & Oturum gündemi \\
\hline $\mathbf{5}$ & $\begin{array}{l}\text { Sonlandırma } \\
\text { Oturumun değerlendirilmesi } \\
\text { Ev ödevi verilmesi }\end{array}$ \\
\hline
\end{tabular}

\begin{tabular}{|c|c|}
\hline $\begin{array}{l}\text { Oturum } \\
\text { sayısı }\end{array}$ & Gündem \\
\hline 1.Oturum & $\begin{array}{l}\text { Araştırmanın tanıtılması ve onam } \\
\text { alınması } \\
\text { Veri toplama anketlerinin } \\
\text { uygulanması (Sosyal sorun çözme } \\
\text { envanterinin doldurulmak üzere } \\
\text { eve verilmesi) } \\
\text { Eğitim programının tanıtılması } \\
\text { Stres ve etkileri }\end{array}$ \\
\hline 2. oturum & Stresle baş etme yolları \\
\hline 3. oturum & Sorun yönelimi ve tarzı \\
\hline 4. oturum & Akılc1 sorun çözme \\
\hline 5. oturum & $\begin{array}{l}\text { Düşünme hataları } \\
\text { Bilisssel yeniden yapılandırma }\end{array}$ \\
\hline 6. oturum & Duygu odaklı baş etme \\
\hline 7. oturum & Ben dili ve asertivite \\
\hline 8. oturum & $\begin{array}{l}\text { Genel tekrar ve özet } \\
\text { Geribildirimlerin alınması } \\
\text { Veri toplama anketlerinin yeniden } \\
\text { uygulanması (Sosyal sorun çözme } \\
\text { envanterinin eve verilmesi) }\end{array}$ \\
\hline
\end{tabular}

Eğitim yeri olarak anabilim dalı salonu kullanılmıştır. Her oturumdan bir gün önce katılımcılara hatırlatma mesajı gönderilmiștir. Öz takip aracı, ev ödevleri ve devamlılık konularında eğitim kontratı yapılmış ve her eğitimde vurgulanmıştır. Bir (1) devamsızlık hakkı tanınmıştır. İki asistana, devamsızlık yaptıkları haftayla ilgili kısa bilgilendirme yapılarak ev ödevleri verilmiştir.

\section{Veri Toplama Araçları}

Araştırmada, Perceived Stress Scale (Algılanan Stres Ölçeği), Maslach Burnout Inventory (Maslach Tükenmişlik Envanteri), Health Promotion Lifestyles Profiles II (Sağlıklı Yaşam Biçimi Davranışları Ölçeği II), Social Problem Solving Inventory (Sosyal Sorun Çözme Envanteri) kullanıldı. Eğitimin başında (0.ay), eğitim bitiminde (2.ay) ve 6.ayda aynı ölçekler uygulandı. Ayrıca eğitim bitiminde (2.ay) tarafımızdan oluşturulan ve eğitimin değerlendirildiği bir anket uygulanmıştır.

1. Algılanan Stres Ölçeği: Cohen, Kamarck ve Mermelstein (1983) tarafindan geliştirilen ve Türkçeye uyarlanan Algılanan Stres Ölçeği (ASÖ)'nin 14 maddelik formu kullanılmıştır. ${ }^{31}$ Ölçek, kişinin hayatındaki birtakım durumların ne derece stresli algılandığını ölçmek için tasarlanmıştır. Maddelerden alınan puanlar toplanarak, yanıtlayıcının algıladığı stres düzeyi belirlenmekte ve yüksek puan, algilanan stres düzeyinin yüksekliğine işaret etmektedir.

2. Maslach Tükenmişlik Envanteri: Maslach ve Jackson (1981) tarafından geliştirilen ölçeğin Türkçe uyarlaması kullanılmıştır. ${ }^{32}$ Ölçek, toplam 22 madde ve 3 alt ölçekten (duygusal tükenme, duyarsızlaşma ve kişisel başarı) oluşmaktadır. Tükenmişliğin yüksekliği duygusal tükenme ve duyarsızlaşma alt ölçeklerindeki yüksek puanı, kişisel başarı, alt ölçeğindeki düşük puanı yansıtmaktadır. Ergin'in ülkemizde yaptığ personeline yönelik norm çalışmasına göre tükenmişlik düzeyleri: duygusal tükenme alt ölçeğinde 27 ve üzeri yüksek, 17-26 normal, 0-16 düşük; duyarsızlaşma alt ölçeğinde 13 ve üzeri yüksek, 7-12 normal, 0-6 düşük; kişisel başarı alt ölçeğinde 0-31 yüksek, 32-38 normal, 39 ve üzeri düşüktür. ${ }^{32}$

\section{Sağlıklı Yaşam Biçimi Davranışları Ölçeği}

II: Walker ve ark., tarafından geliştirilen (1996) ölçeğin Türkçeye uyarlanan formu kullanılmıştır. ${ }^{33}$ Sağlıklı Yaşam Biçimi Davranışları Ölçeği'nde (SYBD) 6 alt ölçek yer almaktadır:

1.Tinsellik; bireyin yaşam amaçlarını, bireysel olarak kendini geliştirme yeteneğini ve kendini ne derecede tanıdığını ve memnun edebildiğini belirler.

2. Beslenme; bireyin öğünlerini seçme ve düzenleme, yiyecek seçimindeki değerlerini belirler.

3. Fiziksel aktivite; sağlıklı yaşamın değişmez bir öğesi olan egzersiz uygulamalarının birey tarafından ne düzeyde uygulandığını gösterir. 
4. Sağlık sorumluluğu; bireyin kendi sağllğ üzerindeki sorumluluk düzeyini, sağlığına ne düzeyde katıldığını belirler.

5.Kişiler arası ilişki; bireyin yakın çevresi ile iletişimini ve süreklilik düzeyini belirler.

6. Stres yönetimi; bireyin stres kaynaklarını tanıma düzeyini ve stres kontrol mekanizmalarını belirler. Ölçekten alınan puanların yükselmesi bireyin belirtilen sağlık davranışlarını yüksek düzeyde uyguladığını göstermiştir.

4. Sosyal Sorun Çäzme Envanteri: D'Zurilla ve Nezu tarafından geliştirilen, Duyan ve Gelbal tarafından Türkçeye uyarlanan Sosyal Sorun Çözme Envanterinin (SSÇE) uzun formu kullanılmıştır. ${ }^{34}$ Sorun Yönelimi Ölçeği (SYÖ; 30 madde) ve Sorun Çözme Becerileri Ölçeği (SÇBÖ; 40 madde) olmak üzere iki ana ölçeğe sahiptir. SYÖ kapsamında biliş, duyuş ve davranış; SÇBÖ kapsamında ise sorunun tanımlaması, seçeneklerin oluşturulması, karar verme, çözümü gerçekleştirme ve doğrulama değerlendirilmektedir. Envanterden alınan puanın yüksek olması, sosyal sorun çözme durumunun yüksekliğini göstermektedir.

5. Ĕ̆itim Değerlendirme Formu: Tarafımızdan oluşturulan eğitim değerlendirme formu, katılımcıların eğitim sonunda kendileri ile ilgili geri bildirimlerini içeren 10 soru ve eğitim programı ile ilgili olan geribildirimlerini içeren 15 soru olmak üzere toplam 25 sorudan oluşmaktadır. Ayrıca katılımcılar her bir soru başlı̆ğına yönelik kendileri ile ilgili ya da eğitim programı ile ilgili açık uçlu geribildirimlerde bulunmuşlardır.

\section{Bunlara ek olarak:}

1. Altıncı ayda ölçekler uygulanırken 'Stres yönetimi ve sosyal sorun çözme ile ilgili verilen eğitimden sonra aldığınız eğitim ile ilgili herhangi bir girişiminiz (kitap alıp okuma, kursa katılım, eğitim esnasında alınan notların gözden geçirilmesi, internet üzerinden araştırma yapma vs.) oldu mu?' sorusu,

2. Eğitimin başında "Son bir yıl içinde"; izlem döneminde (6.ayda) ise "Son altı ay içinde" yaşamlarını etkileyen büyük bir stres (ölüm, hastalık, kaza, ayrılık vb.) yaşayıp yaşamadıkları sorulmuştur.

\section{Verilerin Değerlendirilmesi}

İstatistiksel analizler SPSS 20,0 paket program1 kullanılarak yapılmıştır. Eğitim öncesi ölçek puanlarının, eğitim sonrası ve izlem puanları ile karşılaştırılmasında normal dağılım gösteren veriler için eşleştirilmiş t test ve göstermeyenler için Wilcoxon testi kullanılmıştır. Eğitimle ilgili geribildirimler, ortalama ve niteliksel olarak değerlendirilmiştir. $\mathrm{P}$ değerinin 0,05 'ten küçük olması istatistiksel olarak anlamlı kabul edilmiştir.

\section{BULGULAR}

Çalışmaya katılan 26 asistan hekimin yaş ortalaması $29,8 \pm 3,0 \quad(27-40) \quad y 11, \quad \% 65,4$ 'ü kadındır. Katılımcıların 9'u $(\% 34,6)$ son bir y1l içinde yaşamlarını etkileyen büyük bir stres yaşadıklarını bildirmișlerdir. Eğitim sürecinde ise sadece bir katılımcı stres (annesinde hastalık) yaşadığını bildirmiştir. Yaşanılan stres ile duyarsızlaşma alt ölçeği dışında çalışılan hiçbir ölçek arasında anlamlı bir ilişki bulunamamıștır. Son bir yıl içinde yaşamını etkileyen büyük bir stres yaşamayanlarda duyarsızlaşma alt puanı anlamlı olarak yüksek bulunmuştur $(\mathrm{p}=0,035)$.

Tablo 3'te katılımcıların eğitim öncesi ölçek puan ortalamaları görülmektedir. Ergin'in sağlık personeline yönelik norm çalışmasına göre; çalışma grubunun duygusal tükenme puan ortalaması düşük sınırlarda, duyarsızlaşma puan ortalaması normal sinırlarda ve kişisel başarıda azalma puan ortalamaları yüksek sınırlarda bulunmaktadır. Eğitim sonrası (2.ay) değerlendirmede, kişisel başarı, tinsellik, beslenme, fiziksel aktivite, săglık sorumluluğu, kişilerarası ilişki, stres yönetimi, yönelim, çözüm, SYBD, SSÇE ölçek puan ortalamalarının eğitim öncesine göre olumlu yönde anlamlı değişim gösterdiği; izlem döneminde ise, tinsellik, beslenme, kişilerarası ilişki, stres yönetimi, yönelim, SYBD ve SSÇE puanlarındaki değişimin anlamlı farklılığının devam ettiği görülmüştür. Ancak, uygulanan eğitim programı asistanların algılanan stres, duygusal tükenme ve duyarsılaş̧ma puanlarında herhangi anlamlı bir farklılığa neden olmamıştır (Tablo 3).

İzlem döneminde 'Stres yönetimi ve sosyal sorun çözme ile ilgili verilen eğitimden sonra aldığınız eğitim ile ilgili herhangi bir girişiminiz (kitap alıp okuma, kursa katılım, eğitim esnasında alınan notların gözden geçirilmesi, internet üzerinden araştırma yapma vs.) oldu mu?' sorusuna katılımciların \%80,7'si evet \%19,2'si hayır yanıtını vermişlerdir. Herhangi bir girişimde bulunan grubun SYBD toplam puanı $(132,1)$ ve stres yönetimi puanı $(19,0)$ girişimde bulunmayan gruba göre (sirayla $157,0 ; 23,8)$ anlamlı olarak daha düşüktür (SYBD toplam için $p=0,044$; stres yönetimi için $p=0,018$ ).

\footnotetext{
Katılımcilardan "Oturumlar sirasinda kişisel yaşantımı paylaşabildim" ifadesine katılanların ortalaması en düşük $(3,1 \pm 1,2)$ iken " $\mathrm{Bu}$ eğitimin asistan eğitim programında yer alması gerektiğini düşünüyorum" ifadesine katılanların ortalaması en yüksek $(4,8 \pm 0,3)$ olarak bulunmuştur (Tablo 4). Katılımcıların açık uçlu geribildirimleri Tablo 5'de görülmektedir.
} 


\begin{tabular}{|c|c|c|c|c|c|c|}
\hline & & $\begin{array}{l}\text { Ĕ̆itim öncesi } \\
\text { (EÖ) }\end{array}$ & $\begin{array}{l}\text { Ĕgitim sonrası } \\
\text { (ES) }\end{array}$ & $\begin{array}{l}\text { İzlem } \\
\text { (ं) }\end{array}$ & EÖ-ES* & EÖ- İ* \\
\hline Ölçek & Alt ölçekler & Ortalama $\pm S S$ & Ortalama $\pm S S$ & Ortalama $\pm S S$ & $p$ & $p$ \\
\hline ASÖ & & $26,3 \pm 4,2$ & $27,2 \pm 2,6$ & $26,9 \pm 3,7$ & 0,251 & 0,531 \\
\hline \multirow[t]{3}{*}{ MTE } & $\begin{array}{l}\text { Duygusal } \\
\text { tükenme }\end{array}$ & $12,8 \pm 7,5$ & $10,4 \pm 5,8$ & $11,6 \pm 6,0$ & 0,062 & 0,341 \\
\hline & Duyarsızlaşma & $10,4 \pm 2,9$ & $9,6 \pm 2,2$ & $8,6 \pm 2,6$ & 0,203 & 0,054 \\
\hline & Kişisel başarı & $22,2 \pm 4,6$ & $24,4 \pm 3,7$ & $24,3 \pm 5,1$ & 0,006 & 0,829 \\
\hline \multirow[t]{7}{*}{ SYBD } & Tinsellik & $25,7 \pm 4,4$ & $29,0 \pm 4,0$ & $27,4 \pm 4,9$ & 0,000 & 0,046 \\
\hline & Beslenme & $21,0 \pm 3,1$ & $24,0 \pm 4,2$ & $23,2 \pm 4,9$ & $0,000 * *$ & $0,024 * *$ \\
\hline & Fiziksel aktivite & $16,1 \pm 5,8$ & $19,2 \pm 6,9$ & $17,4 \pm 7,1$ & $0,005 * *$ & $0,200 * *$ \\
\hline & $\begin{array}{l}\text { Sağlık } \\
\text { sorumluluğu }\end{array}$ & $20,8 \pm 3,9$ & $23,0 \pm 4,9$ & $21,7 \pm 4,9$ & 0,010 & 0,323 \\
\hline & Kişilerarası ilişki & $25,6 \pm 4,1$ & $28,1 \pm 4,6$ & $27,1 \pm 5,6$ & 0,001 & 0,042 \\
\hline & Stres yönetimi & $17,4 \pm 3,5$ & $21,0 \pm 3,3$ & $19,9 \pm 4,1$ & 0,000 & 0,001 \\
\hline & SYBD toplam & $126,9 \pm 18,8$ & $144,6 \pm 19,8$ & $136,9 \pm 24,9$ & 0,000 & 0,009 \\
\hline \multirow[t]{3}{*}{ SSÇE } & Yönelim & $75,3 \pm 21,2$ & $88,6 \pm 15,6$ & $89,2 \pm 18,0$ & 0,000 & 0,000 \\
\hline & Çözüm & $107,8 \pm 23,3$ & $120,5 \pm 21,5$ & $115,8 \pm 27,4$ & 0,001 & 0,134 \\
\hline & SSÇE toplam & $183,1 \pm 40,3$ & $209,1 \pm 34,5$ & $205,0 \pm 41,3$ & 0,000 & 0,003 \\
\hline
\end{tabular}

EÖ: 0.ay, ES: 2.ay, İ: 6.ay*Eşleştirilmiş t testi **Wilcoxon test

Tablo 4. Katılımcıların kendileri ile ilgili geribildirim ortalamaları

\begin{tabular}{|c|c|c|}
\hline & Ort \pm SS & $\begin{array}{l}\text { Min-Max } \\
\text { (Ortanca) }\end{array}$ \\
\hline 1. Bu eğitimde önerilen öz takip araçlarını kullandım & $4,1 \pm 0,7$ & $3-5(4)$ \\
\hline 2. Bu eğitimde verilen ev ödevlerini yaptım & $3,8 \pm 0,6$ & $3-5(4)$ \\
\hline 3. Bireysel ve grup çalışmalarına aktif olarak katıldım & $4,5 \pm 0,6$ & $3-5(5)$ \\
\hline 4. Oturumlar sırasında kişisel yaşantımı paylaşabildim & $3,1 \pm 1,2$ & $1-5(3)$ \\
\hline 5. Bu eğitimde öğrendiklerimi günlük yaşamımda uygulayabildim & $3,6 \pm 0,7$ & $2-5(4)$ \\
\hline $\begin{array}{l}\text { 6. Bu eğitim, konuyla bilgi ve beceri gereksinimlerimi belirlememe } \\
\text { yardımcı oldu }\end{array}$ & $4,4 \pm 0,7$ & $3-5(5)$ \\
\hline $\begin{array}{l}\text { 7. Bu eğitimde kazandığım bilgi ve becerileri kullanabileceğim } \\
\text { (kendim için). }\end{array}$ & $4,3 \pm 0,6$ & $3-5(4)$ \\
\hline $\begin{array}{l}\text { 8. Bu eğitimde kazandığım bilgi ve becerileri kullanabileceğim } \\
\text { (hastalarım için). }\end{array}$ & $3,7 \pm 0,8$ & $2-5(4)$ \\
\hline $\begin{array}{l}\text { 9. Bu eğitimin asistan eğitim programında yer alması gerektiğini } \\
\text { düşünüyorum. }\end{array}$ & $4,8 \pm 0,3$ & $4-5(5)$ \\
\hline 10. Genel olarak bu eğitim programından yararlandım & $4,5 \pm 0,5$ & $3-5(5)$ \\
\hline
\end{tabular}

Katılımcıların, eğitim programı ile ilgili geribildirimlerinde eğitim programının uygulanma zamanı (öğle arası) ile ilgili geribildirim puanı en düşük $(3,0 \pm 0,9)$ iken eğiticinin konuyu aktarmadaki becerisi ile ilgili geribildirim puanı en yüksektir
$(4,9 \pm 0,1)$ (Tablo 6). Katılımcıların eğitim programı ile ilgili açık uçlu geribildirimleri Tablo 7'de verilmiştir. 


\section{Tablo 5. Katılımcıların kendileri ile ilgili açık uçlu geribildirimleri}

\section{Başıklar}

1. Bu eğitimde önerilen öz takip araçlarını kullandım

2. $\mathrm{Bu}$ eğitimde verilen ev ödevlerini yaptım

3. Bireysel ve grup çalışmalarına aktif olarak katıldım

4. Oturumlar sırasında kişisel yaşantımı paylaşabildim

5. $\mathrm{Bu}$ eğitimde öğrendiklerimi günlük yaşamımda uygulayabildim

6. Bu eğitim, konuyla bilgi ve beceri gereksinimlerimi belirlememe yardımci oldu

7. $\mathrm{Bu}$ eğitimde kazandığım bilgi ve becerileri kullanabileceğimi düşünüyorum (kendim için).

8. $\mathrm{Bu}$ eğitimde kazandığım bilgi ve becerileri kullanabileceğimi düşünüyorum (hastalarım için).

9. Bu eğitimin asistan eğitim programında yer alması gerektiğini düşünüyorum.

10. Genel olarak bu eğitim programından yararlandım

\section{Başlıklara yönelik açık uçlu cevaplar (Asistan no)}

Kendi yoğunluğumdan dolayı firsat bulamadım (2), Öztakip aracını bölümde sabitlemek (unutulmasını engellemek için) (13), Kendi hatamdi takip etmeliydim (16)

Kendi yoğunluğumdan dolayı firsat bulamadım (2), Ev ödevlerini aynı gün içinde yapmam gerekirdi (7), Kendi hatamd takip etmeliydim (16)

Çok özel sorunları paylaşmak istemedim (2)

Küçük gruplar ya da bireysel görüşmeler yapılabilir (1), Birebir oturum şansımız olmadığ 1 için kendimi yansıtamadım (ama zaten vakit sınıllıdı) (5), Katılım sayısı az olsaydı özel yaşantımı paylaşabilirdim (13), Oturumlar sırasında kişisel yaşantımı sınırlı paylaştım. Belki çalışma arkadaşlarımın olmadığı bir grup olsa daha rahat paylaşılabilirdi (24), Gruplar daha az olsa özel yaşantımı ayrıntılı paylaşabilirdim (26)

$\mathrm{Bu}$ konuda benim çaba göstermem gerekir (1). Benden kaynaklı olduğu için geliştirilmesi gereken bir durum değil (7). Kendi hatamdi takip etmeliydim (16). Gerekli becerileri kazandıktan sonra günlük yaşantıma geçirebilirim (26)

Kitap eksiğimin olduğunu fark ettim (26)

Hastalara da bu tarz bir eğitim verilmeli (13). Hastaları eğitim düzeyiyle değişmekle birlikte bu tarz yaklaşımla herşeyi çözebileceğimi düşünmüyorum (16). Hastalar için bu beceriyi kullanabilmenin çok fazla tecrübe gerektirdiğini düşünüyorum. $\mathrm{Bu}$ seviyede olabilmek için çok çalışmam gerektiğini düşünüyorum (24)

Bu eğitim bize tıp fakültesinin ilk yıllarında verilmeli (26)

Tablo 6. Katılımcıların eğitim programı ile ilgili geribildirim ortalamaları

1. Fizik ortam

2. Organizasyon (Öncesi ve sonrası bilgilendirme)

3. Eğitim programının uygulanma zamanı (öğle arası)

4. Eğitim programının uygulanma günü (Çarşamba)

5. Bir oturum süresi (1 saat)

6. Oturumların sıklığı (haftada bir)

7. Toplam oturum sayısı ( 8 oturum)

8. Oturumların içeriği ve akışı

9. Eğiticinin konuyu aktarmadaki becerisi

10. Eğiticinin eğitim sırasındaki tutum ve davranışları

11. Eğitim sırasındaki bireysel çalışmalar

12. Eğitim sırasındaki grup çalışmaları

13. Ev ödevleri

14. Öz takip araçları

15. Okuma önerileri
Ort \pm SS

$3,9 \pm 0,5$

$4,5 \pm 0,5$

$3,0 \pm 0,9$

$3,6 \pm 0,8$

$3,7 \pm 0,8$

$3,5 \pm 0,9$

$3,6 \pm 1,0$

$4,7 \pm 0,4$

$4,9 \pm 0,1$

$4,8 \pm 0,3$

$4,1 \pm 0,7$

$4,2 \pm 0,7$

$3,9 \pm 0,6$

$3,8 \pm 0,8$

$4,6 \pm 0,4$
Min-Maks (Ortanca)

2-5 (4)

3-5 (5)

$1-5(3)$

$2-5(4)$

2-5 (4)

2-5 (4)

2-5 (4)

4-5 (5)

4-5 (5)

$4-5(5)$

$3-5(4)$

3-5 (4)

3-5 (4)

$2-5$ (4)

$4-5(5)$ 


\begin{tabular}{|c|c|}
\hline Başlıklar & Başlıklara yönelik açık uçlu cevaplar (Asistan no) \\
\hline 1. Fizik ortam & \\
\hline $\begin{array}{l}\text { 2. Organizasyon (Öncesi ve } \\
\text { sonrası bilgilendirme) }\end{array}$ & \\
\hline $\begin{array}{l}\text { 3. Eğitim programının uygulanma } \\
\text { zamanı (öğle arası) }\end{array}$ & $\begin{array}{l}\text { Daha uzun bir eğitim olması gerektiğgini düšünüyorum, daha çok } \\
\text { uygulama yapabilmek için (1), Öğle arası bir koşuşturmaca } \\
\text { şeklinde olması zorladı (yoğunluk, poliklinik çalıştı̆ımızdan } \\
\text { dolayı (2), Konsantrasyon sağlamada zorlandım, yemek sonrası } \\
\text { olması nedeniyle (5), Salı ve Perşembe günleri seminer günleri } \\
\text { olması nedeniyle başka bir öğle arasının da bu çalışmaya ayrılış } \\
\text { olması, zaman planlama, yetişme açısından zorlanmama sebep oldu } \\
\text { (6), Eğitim saati çok yanlış bir zamandaydı, dinlenme vaktinde ders } \\
\text { iyi olmadı. Hafta sonları daha uygun zaman olabilir (11), Öğle arası } \\
\text { yerine belirlenen günde öğleden sonraki mesai saatlerinde olmalı } \\
\text { (16), Öğle arası hepimiz müsait olmayabiliyoruz bazen yetişmemiz } \\
\text { yemek yememiz zor olabiliyor (23), Bu program öğle arası yerine } \\
\text { daha geniş bir zamanda yapıplabilir (25), Eğitim programı öğle aras1 } \\
\text { yerine avr bir günde olmalı (26) }\end{array}$ \\
\hline $\begin{array}{l}\text { 4. Eğitim programının uygulanma } \\
\text { günü (Çarşamba) }\end{array}$ & \\
\hline 5. Bir oturum süresi (1 saat) & Oturum süresi daha uzun olmalı (26) \\
\hline 6. Oturumların sıklığ (haftada bir) & $\begin{array}{l}\text { Daha sık oturumlar daha hatıllatıcı ve kalıcı olur diye düşünüyorum } \\
\text { (1), Daha s1k aralıklarla olmasını isterdim (5), Daha s1k biraraya } \\
\text { gelinebilirdi (23), Oturum sıklığ } 1 \text { 3-4 güne bir olmalı (26) }\end{array}$ \\
\hline $\begin{array}{l}\text { 7. } \begin{array}{l}\text { Toplam } \\
\text { oturum })\end{array} \\
\text { oturum }\end{array}$ & $\begin{array}{l}\text { Oturum sayısının artması içeriğin daha ayrıntılı konuşulması için } \\
\text { bir firsat olabilir (1), Oturum sayısı daha fazla olabilirdi }(6) \text {, } \\
\text { Oturum sayısı yetersiz (11), Oturum sayısı arttırılmalı (16) }\end{array}$ \\
\hline 8. Oturumların içeriği ve akışı & \\
\hline $\begin{array}{l}\text { 9. Eğiticinin konuyu aktarmadaki } \\
\text { becerisi }\end{array}$ & \\
\hline $\begin{array}{l}\text { 10. Eğiticinin eğitim sırasındaki } \\
\text { tutum ve davranışları }\end{array}$ & \\
\hline $\begin{array}{l}\text { 11. Eğitim sırasındaki bireysel } \\
\text { çalışmalar }\end{array}$ & $\begin{array}{l}\text { Bu çalışmaların bireysel oturumlarla zenginleştirilmesi gerekiyor } \\
\text { (1) }\end{array}$ \\
\hline $\begin{array}{l}\text { 12. Eğitim sırasındaki grup } \\
\text { çalışmaları }\end{array}$ & \\
\hline 13. Ev ödevleri & $\begin{array}{l}\text { Ev ödevlerini yapmaya kendim firsat bulamadım. Öneri: zaman } \\
\text { olup burada yapılsa daha iyi olabilirdi (2), Ev ödevlerini de bu } \\
\text { zaman içinde yaparak hem unutmanın önüne geçeriz hem de } \\
\text { eğitimin hemen ardından daha faydalı bir şekilde yaparı (25) }\end{array}$ \\
\hline 14. Öz takip araçları & $\begin{array}{l}\text { Elimizde kaynak bulunmasını isterdim (5), Kendi not tuttuğumuz } \\
\text { araçlar yerine basılı olabilirdi (6) }\end{array}$ \\
\hline 15. Okuma önerileri & \\
\hline
\end{tabular}

\section{TARTIŞMA}

Stres yönetimi ve sorun çözmeyle ilgili sekiz haftalık bir psikoeğitim programının etkisini sınamak amaciyla yapılan bu çalışmada, verilen eğitimin aile hekimliği asistanlarının sağlık davranışları ve sorun çözme puanlarını olumlu yönde etkilediği ortaya konmuștur. Bununla birlikte, eğitim bitiminde istatistiksel olarak anlamlı olmasa da tükenmişlik puanları olumlu yönde değişirken algılanan stres puanının artması, bunun olumlu stres olarak algılandığını düşündürmüştür. Bir miktar stres ya da olumlu stres, özellikle iş ortamlarında bireyin becerisine ve iş görme gücüne yardımcı olan bir coşku, bir enerji şeklinde bireye fayda sağlayabilmekte, psikososyal gelişim için gerekli olabilmektedir. ${ }^{35}$ Çalışmamızla uyumlu olarak, Gunasingam ve arkadaşları yaptıkları prospektif randomize kontrollü çalışmada (2015), birinci yıl hekimlere, çalıştıkları hastanede iki haftada bir, mesai sonrası yaklaşık bir saat, dört oturumdan oluşan bir girişimde bulunmuşlar ancak tükenmişlik puanlarında anlamlı bir iyileşme elde edememişlerdir. ${ }^{36}$ 
Osmipa-Krammer ve arkadaşları (2003), 23 aile hekimliği asistanıyla yaptıkları çalışmada ROM (Respiratory-one method) nefes egzersizinin duygusal tükenme puanlarında meditasyona benzer iyileşme gösterdiğini saptamışlardır ${ }^{37}$. Feld ve arkadaşları (2006), profesyonel gelişim içindeki bir girişim programının asistanların özfarkındalıklarını ve duygularını araştırma isteklerini arttırdığını bulmuşlardır. $\mathrm{Bu}$ program açık tartışma ve sorun çözmeyi içeren 11 oturumdan oluşmuştur ve gündem maddelerini grup belirlemiştir. ${ }^{38}$ Gardiner ve arkadaşlarının (2004), 85 Avusturalyalı aile hekimine verilen stres reaksiyonu, psikoeğitim, gevşeme teknikleri ve bilişsel müdahaleyi içeren 15 saatlik bir stres yönetimi eğitiminin etkisini değerlendirdikleri çalışmada, kursun başlangıcını takip eden 12 haftalık sürede katılımcıların işle ilgili stres düzeylerinde anlamlı azalma, genel iyilik halleri ve yaşam kalitelerinde ise artma saptamışlardır. ${ }^{39}$ Krasner ve arkadaşları (2010), iletişim ve kişisel farkındalık konularında yoğun bir eğitim programının birinci basamak hekimlerin iyilik hali, psikolojik distresi, tükenmişliği ve hastalarla ilişki kurma kapasitesine etkisini araştırmışlardır. Gönüllü 70 birinci basamak hekimine 8 haftası yoğun faz (2,5 saat/hafta, artı bir tam gün (7 saat)) ardından 10 ay sürdürme fazı (2,5 saat/ay) olacak şekilde eğitim vermişler ve başlangıçta, 2., 12. ve 15.ayda değerlendirme yapmışlardır. Hem kısa, hem de uzun dönemde hekimlerin tükenmişlik puanlarında azalma, iyilik halleri ve hasta merkezli bakım tutumlarında iyileşme görülmüştür. ${ }^{40}$ Fortney ve arkadaşları ise (2013), uzun süren eğitimlerde zaman sorunu nedeniyle çalışmadan ayrılan çok fazla olduğu ve kısa süreli eğitimlerde de olumlu sonuçlar alınabildiği fikriyle aynı eğitimin kısaltılmış (8 hafta) modifiye formunun etkisini araştırmışlardır. Otuz birinci basamak hekimi ile yaptıkları çalışmada, tükenmişlik, anksiyete, stres, dayanıklılık ve sevecenlik (merhamet) başlıklarını içeren kısaltılmış farkındalık eğitiminden sonra kursa katılan birinci basamak klinisyenlerinin duygusal tükenme, duyarsızlaşma ve algılanan stres puan ortalamalarında anlamlı azalma, kişisel başarı puan ortalamalarında anlamlı artma saptamışlardır (1. gün, 8. hafta, 9. ayda). ${ }^{41}$ Bu çalışma ile uyumlu olarak çalışmamızda eğitimden sonra duygusal tükenme ve duyarsızlaşma puan ortalamalarında azalma, kişisel başarı puan ortalamasında artış bulunmuştur. Bu değişimlerden sadece kişisel başarı puanının 2 . aydaki artışı istatistiksel olarak anlamlıdır.

Çalışmamızın, eğitim içeriğinin daha çok bilişsel düzeyde olması, sadece bir oturumun gevşemeye yönelik uygulamalar içermesi algılanan stres, duygusal tükenme ve duyarsızlaşma puanlarında değişikliklerin anlamlı boyutta olmamasının nedeni olabilir. Bir diğer nedeni, Ergin'in sağlık personeline yönelik norm çalışmasına göre; çalışma grubunun ortalama duygusal tükenme ve duyarsızlaşma düzeylerinin zaten düşük ve normal sınırlarda olması olabilir. Ayrıca, çalışılan ölçeklerden sadece duyarsızlaşma ölçeğinin yaşanılan stresle ilişkili bulunması, stres (ölüm, hastalık, kaza, ayrılık vb.) yaşadığını bildiren grubun duyarsızlaşma puanının anlamlı olarak daha düşük olması dikkat çekicidir. Ölüm, hastalık, kaza, ayrılık vb. gibi olayların empati ve merhamet duygularını arttırarak bu etkiyi yaratmış olabileceği düşünülebilir.

Katılımcıların eğitim sonunda verdikleri geri bildirimler genel olarak olumlu bulunmuştur. Açık uçlu geribildirimler incelendiğinde grubun kalabalık ve tanıdık olmasının kişisel yaşantılar ile ilişkili paylaşımları azalttı̆̆ı, kişisel yoğunluklar nedeniyle öztakip aracı kullanma ve ev ödevi yapma konusunda sıkıntı yaşandığı belirlenmiştir. Eğitim programı ile ilgili geribildirimlerde eğitim programının uygulanma zamanı (öğle arası) ve oturumların sıklığı (haftada bir) ifadelerinden alınan ortalama puanlar en düşüktür. Açık uçlu geribildirimler incelendiğinde, eğitimin öğle arasında yapılmasının bazı rotasyonlarda çalışma saatinin öğle arasına sarkması, yemek ve kişisel ihtiyaçlar için gereken zamanın kısıtlanması nedeniyle ayrı bir stres kaynağı yarattığı düşünülmüştür. Eğitim programının genel olarak yararlı olduğu ancak daha sık, daha uzun, daha çok olması, öğle arası yerine daha geniş zaman dilimlerinde yapılması yönünde görüş bildirilmiştir. Öğle arası planlanmasının nedeni bu programın haftada iki gün öğle arası yapılan formal eğitim programına entegre edilip edilemeyeceğini sınamaktı. Ancak didaktik eğitimlerden farklı olduğu için öğle arasının uygun olmadığı, mesai sonras1 veya hafta sonlar1 daha uzun oturumlar şeklinde planlanabileceği düşünülmüştür.

Çalışmanın 6. ayında yapılan değerlendirmede, katılımcıların \%80,7'sinin eğitimden sonraki süreçte eğitim ile ilgili araştırmaya, öğrenmeye devam etmesi olumlu olarak değerlendirilmiştir. Ancak herhangi bir girişimde bulunan grubun stres yönetimi ve sağlıklı yaşam biçimi davranışları toplam puanlarının bulunmayan gruba göre anlamlı olarak daha düşük çıkması dikkat çekici bulunmuştur. Stres yönetimi ve sağlıklı yaşam biçimi konularında kendini geliştirme ihtiyacı hisseden, dolayısıyla puanları daha düşük olan katılımcıların girişimde bulunmuş olabilecekleri düşünülmüştür. 
$\mathrm{Bu}$ çalışmayla, aile hekimi asistanlarının stres algıları, tükenmişlik düzeyleri, sağlık davranışları ile sosyal sorun çözme becerileri değerlendirilmiş ve talep edenlere geri bildirim verilerek farkındalık yaratılmıştır. Asistanlar normal eğitim programında yer almayan, kendileri ve hastaları için kullanabilecekleri bir eğitim alarak bilgi ve becerilerini arttırmışlardır. Bununla birlikte, verilen psikoeğitimin kisa ve uzun dönemdeki olumlu etkileriyle ve asistanların geribildirimleriyle bu konudaki eğitim gereksinimi ortaya konulmuştur.

Her araştırmada olduğu gibi çalışmanın kısıtlı yönleri de vardır. Bir kısmı kullanılan yöntemlerin özelliklerine bağlı olan kısıtlılıklar:

1.Eğitimi veren kişi ile araştırmacının aynı kişi olması (eğitici ve eğitim ortamının tanıdık olmasının değişikliğin ortaya çıkaracağı etkileri ve karıştırıcı faktörleri azaltacağı da düşünülebilir),

2.Kullanılan eğitim yönteminin, asistanların alışık olduklarından farklı bir ders işleme sürecini gerektirmesi (farklı bir yöntem denenmediğinde deneysel çalışmanın da olamayacağı gerçeği ve genelde deneysel çalışmalarda durumun böyle olması),

3.Kontrol grubunun olmaması (başka yerlerde eğitim alan aile hekimliği asistanlarının stres faktörlerinin farklı olabileceği, çalışma grubunun ikiye bölünerek kontrol grubu oluşturulması durumunda ise süreç içerisinde eğitim alan grubun bekleyen grubu etkileyebileceği ön görülerek çalışma kendi kendine kontrollü olarak yapılmıştır),

4.Asistanların deneysel bir çalışma yürütüldüğünden haberlerinin olması, kendilerinden olumlu yönde değişim umdukları varsayımında olmaları ve bu beklentiyi boşa çıkarmamak için özel bir çaba içine girme olasılıkları (Hawhortne etkisi),

5.Her ne kadar aydınlatılmış onam alınsa da ast-üst ilişkisi nedeniyle asistanların çalışmaya katılım konusunda kendilerini zorunlu hissetmiş olabilecekleri,

6.Bir kısmı eve verilse de asistanların çok fazla anket doldurmak durumunda kalmalarının verilen cevapları etkilemiş olabileceği.

\section{SONUÇ}

Sonuç olarak, aile hekimliği asistanlarına verilen sekiz saatlik stres yönetimi ve sorun çözme içerikli psikoeğitimin, hem kısa (iki ay), hem de uzun (altı ay) dönemde olumlu etkileri görülmüştür. Kişisel başarı, tinsellik, beslenme, fiziksel aktivite, sağlık sorumluluğu, kişilerarası ilişki, stres yönetimi, yönelim, çözüm, sağlıklı yaşam biçimi davranışları toplam, sosyal sorun çözme toplam ölçek puan ortalamalarının eğitim öncesine göre anlamlı değişim gösterdiği; izlem döneminde, tinsellik, beslenme, kişilerarası ilişki, stres yönetimi, yönelim, sağlıklı yaşam biçimi davranışları toplam ve sosyal sorun çözme toplam puanlarındaki değişimin anlamlı farklılığının devam ettiği görülmüştür. Ancak, uygulanan eğitim programı asistanların algılanan stres, duygusal tükenme ve duyarsızlaşma puanlarında olumlu yönde değişime yol açmasına karşın bu farklılık istatistiksel olarak anlamlı bulunmamıştır.

Asistanlarda stres, tükenmişlik, sağlıklı yaşam davranışları konularında durum tespitinden öte daha çok girişimsel çalışmalara gereksinim olduğu göz önüne alındığında bulgularımızın konuyla ilgili yapılması planlanan eğitim veya girişimler için umut verici ve yol gösterici olacağ1 düşünülmüştür. Uygulamaya veya araştırmaya yönelik öneriler aşağıda sıralanmıştır:

1.Uygulanan eğitim programı geribildirimlerle geliştirilip, daha uzun dönem etkileri kısıtlılıkları en aza indirecek yöntemlerle sinanabilir.

2.Bundan sonra yapılacak girişimlerde, oturumların bir kısmının gündeminin katılımcılar tarafından belirlenmesi, gevşemeye yönelik etkinlikler eklenmesi, pekiştirme ve güçlendirme için belirli aralıklarla ek oturumlar yapılması planlanabilir.

3.Stres yönetimi, sosyal sorun çözme, sağlıklı yaşam alışkanlıkları ile ilgili etkili eğitim programları geliştirilip, bu eğitim programlarının uzmanlık eğitim müfredatına yerleştirilmesi ile ilgili çalışmalar yapılabilir.

4.Bireyi güçlendirmeye yönelik girişimlerin yanı sıra kurumsal düzeyde girişimler yapılabilir.

\section{REFERENCES}

1. Soler JK, Yaman H, Esteva M, Dobbs F, Asenova RS, Katić M, et al. Burnout in European family doctors: the EGPRN study. Fam Pract 2008;25(4):245-65.

2. Romani M, Ashkar K. Burnout among physicians. Libyan J Med 2014;17;9:1-9.

3. Lee FJ MD, Stewart M PhD, Brown JB. Stress, burnout, and strategies for reducing them what's the situation among Canadian family physicians? Can Fam Physician 2008;54:23435.

4. Goehring C, Gallacchi MB, Künzi B, Bovier P. Psychosocial and professional characteristics of 
burnout in Swiss primary care practitioners: a cross-sectional survey. Swiss Med Wkly 2005;135:101-8.

5. Kaçmaz N. Tükenmişlik (Burnout) Sendromu. İst Tip Fak Derg 2005;68: 29-32.

6. Dyrbye LN, Thomas MR, Shanafelt TD. Systematic review of depression, anxiety, and other indicators of psychological distress among U.S. and Canadian medical students. Acad Med 2006; 81:354-73.

7. Levey RE. Sources of stress for residents and recommendations for programs to assist them. Acad Med 2001; 76(2): 142-50.

8. McCray LW, Cronholm PF, Bogner HR, Gallo JJ, Neill RA. Resident physician burnout: Is there hope? Fam Med 2008;40(9):626-32.

9. Lebensohn P, Dodds S, Benn R, R., Brooks AJ, Birch M. Resident wellness behaviors: relationship to stres, depression, and burnout. Fam Med 2013;45(8):541-9.

10. Efeoglu IE, Ozcan S. Work family conflict and its association with job performance and family satisfaction among physicians. Australian Journal of Basic and Applied Sciences 2013;7(7): 43-48.

11. Alosaimi FD, Kazim SN, Almufleh AS, Aladwani BS, Alsubaie AS. Prevalence of stress and its determinants among residents in Saudi Arabia. Saudi Med J 2015;36 (5):605-12.

12. Akçakaya RÖ, Erden SÇ. Stres ve stresle baş etmede psikiyatrik yaklaşım. Turkish Family Physician 2014; 5(2):18-25.

13. Khoury B, Ammar J. Cognitive behavioral therapy for treatment of primary care patients presenting with psychological disorders. Libyan J Med 2014, 9: 24186

14. Eskin M. Sorun Çözme Terapisi, 3.Bask1, Ankara: HYB Yayıncılık. 2009.

15. D' Zurilla TJ, Nezu AM. Problem- solving therapy: a positive approach to clinical intervention, third edition. Springer Publishing Company, 2007.

16. Pierce D. Problem solving therapy use and effectiveness in general practice. Aust Fam Physician 2012;41(9):676-9.

17. Oberg EB, Frank E. Physicians' health practices strongly influence patient health practices. J R Coll Physicians Edinb 2009;39(4):290-91.

18. Çeler A, Kara İH, Baltacı D, Çeler H. Tıp fakültesi'ndeki araştırma görevlilerinde depresyon düzeyinin iş doyumu ile ilişkisinin incelenmesi. Konuralp Tip Dergisi [Konuralp Medical Journal] 2015; 7(3):125-133.

19. Sayın S, Kara İH, Baltacı D, Yilmaz A. Tip fakültesinde görev yapan araştırma görevlilerinde kronik yorgunluk ve depresyon sıklığının incelenmesi. Konuralp Tıp Dergisi [Konuralp Medical Journal] 2013; 5(1):11-7.

20. Ersoy S, Kavalcı C, Yel C, Yılmaz F, Kavalcı G, Aslan Ö. Tıp Fakültesi Hastaneleri ve Sağlık
Bakanlığg Eğitim ve Araştırma Hastaneleri’nde çalışan acil tıp asistanlarının tükenmişlik düzeylerinin karşılaştırılması. Ankara Medical Journal 2014; 14(2):41-5.

21. Yaman H, Ungan M. Tükenmişlik: Aile hekimliği asistan hekimleri üzerinde bir inceleme. Türk Psikoloji Dergisi 2002;17(49):37-44.

22. Marakoğlu K, Kargın NÇ, Armutlukuyu M. Tıp fakültesi araştırma görevlilerinde tükenmişlik sendromu ve ilişkili faktörlerin değerlendirilmesi. Genel Tip Dergisi 2013;23:102-8.

23. Dikmetaş E, Top M, Ergin G. Asistan hekimlerin tükenmişlik ve mobbing düzeylerinin incelenmesi. Türk Psikiyatri Dergisi 2011;22:137-49.

24. Can H, Güçlü YA, Dogan S, Erkaleli MB. Cerrahi ve cerrahi dışı kliniklerdeki asistan hekimlerde tükenmişlik sendromu. Tepecik Eğit Hast Derg 2010;20(1): 33-40.

25. Aslan H, Bengi GS, Alparslan ZN. Tipta uzmanlık öğrencisi hekimlerde tükenme düzeyleri. Türk Psikiyatri Dergisi 1996; 7 (1): 39-45.

26. Almila E, Sariçiçek A, Gülseren Ş. Asistan hekimlerde tükenmişlik: iş doyumu ve depresyonla ilişkisi. Anadolu Psikiyatri Dergisi 2007; 8(4): 241-7.

27. Dabak R, Özçınar M, Sargın M, Özçınar M, Dabak R. Asistan doktorlarda tükenme (burnout) sendromu. Türk Aile Hek Derg 2007; 11(2): 67-71.

28. Abut YC, Kitapcioglu D, Erkalp K, Toprak N, Boztepe A, Sivrikaya U, et al. Job burnout in 159 anesthesiology trainees. Saudi J Anaesth 2012; 6: 46-51.

29. Aysan E, Köroğlu G, Türkel V, Özgönül A, Özyaşar, Gülümser Ç, et al. Resident physicians in Turkey: results of a survey of 1069 residents from 11 provinces. Turk J Med Sci 2008; 38(1): 35-42.

30. Daele TV, Hermans D, Audenhove CV. Stress reduction through psychoeducation: a metaanalytic review. Health Education \& Behavior 2015;39(4) 474-85.

31. Eskin M, Harlak H, Demirkıran F, Dereboy Ç. Algılanan stres ölçeğinin Türkçeye uyarlanması: güvenirlik ve geçerlik analizi. New Symposium Journal 2013;51(3):132-40.

32. Ergin C. Doktor ve hemşirelerde tükenmişlik ve Maslach Tükenmişlik Ölçeğinin Uyarlanması. Türk Psikologlar Derneği Yayınları, Ankara,1992;143-54.

33. Bahar Z, Beşer A, Gördes N, Ersin F, Kıssal A. Sağlıklı yaşam biçimi davranışları ölçeği II'nin geçerlik ve güvenirlik çalışması. C.Ü. Hemşirelik Yüksekokulu Dergisi 2008; 12(1):113. 
34. Duyan V, Gelbal S. Sosyal sorun çözme envanteri'nin Türkçeye uyarlama çalışması. Toplum ve Sosyal Hizmet 2008;19(1):7-28.

35. Baltaş Z, Baltaş A. Stres ve Başa Çıkma Yolları. 31. Basım, İstanbul: Remzi Kitabevi, 2013

36. Gunasingam N, Burns K, Edwards JJ, Dinh M, Walton M. Reducing stress and burnout in junior doctors: the impact of debriefing sessions. Postgrad Med J. 2015; 91(1074):1827.

37. Ospina-Kammerer V, Figley CR. An evaluation of the respiratory one method (ROM) in reducing emotional exhaustion among family physician residents. Int J Emerg Ment Health. 2003; 5(1): 29-32.

38. Feld J, Heyse-Moore L. An evaluation of a support group for junior doctors working in palliative medicine. Am J Hosp Palliat Care 2006; 23(4):287-96.

39. Gardiner M, Lovell G, Williamson P. Physician you can heal yourself cognitive behavioral training reduces stress in GPs. Fam Pract 2004; 21(5): 545-51.

40. Krasner M, Epstein RM, Beckman H, Suchman AL, Chapman B, Mooney CJ. Association of an educational program in mindful communication with burnout, empathy, and attitudes among primary care physicians. JAMA 2009;302(12):1284-93.

41. Fortney L, Luchterhand C, Zakletskaia L, L., Zgierska A, Rakel D. Abbreviated mindfulness intervention for job satisfaction, quality of life, and compassion in primary care clinicians: a pilot study. Ann Med 2013;11(5): 412-20. 